\title{
The Implementation of Module Based on Jigsaw Learning Model to Improve Students' Grammar Understanding for Non Formal School (Package B) Students in Pariaman City
}

\author{
Wienda Gusta ${ }^{1}$, Dian Christina², and Zakirman ${ }^{3}$ \\ ${ }^{1}$ Universitas Putra Indonesia Padang, Indonesia, wienda84@yahoo.com \\ ${ }^{2}$ Universitas Putra Indonesia Padang, Indonesia, Dianchristina@ upiyptk.ac.id \\ ${ }^{3}$ Universitas Putra Indonesia, Padang, Indonesia, Zakirman.official@gmail.com
}

\begin{abstract}
This research is motivated by the limitation of English language teaching materials in a non-formal institution of Pariaman city that can improve students' grammar understanding. The purpose of this study is to see a comparison of students' grammar understanding before and after the implementation of a module based on the jigsaw learning model. The type of this research is quasi-experimental, with a total sample of 15 package B students enrolled in PKBM Center BKM Bina Saiyo in Pariaman with academic year of 2018/2019. The data analysis technique used is the parametric statistical test in the form of a paired sample t-test. The conclusion of this study is that there is a significant difference in grammar understanding before and after using the Jigsaw learning module.
\end{abstract}

Keywords: Module, Jigsaw, Grammar understanding, Package B

\section{INTRODUCTION}

Learning English means also learning about grammar. In English this is commonly called grammar. Grammar is the science of rules in forming and combining words into a sentence that has meaning. Grammar is one of the skills that requires students' analytical skills related to the pattern and arrangement of sentences [10]. By understanding grammar this will help students to improve their knowledge of English both verbally and in writing and be able to interpret English properly and correctly. In English lessons, grammar material is always included in the Package B learning program where the program is equivalent to junior high school.

The facts found in the field, especially in the pursuit of education package B PKBM Pariaman region that students' grammar knowledge is still low. This is evidenced by the short tests that have been conducted and it can be concluded that only $20 \%$ of students can answer correctly. The low knowledge of students' grammar can be caused by several factors including, the limited teaching materials used by teachers in English learning activities in package B education programs, the intensity of meeting times that are not the same as formal education and the lack of variety of learning models used so that they cannot motivate students in learning activities. In addition, during the implementation of learning there were problems encountered by students, including the following: the activeness and interest of students in participating in learning was still lacking, the independence and responsibility of students in doing assignments was still low due to students' lack of understanding of the material presented. This illustrates the effectiveness of teaching and learning in the classroom is still low, causing student achievement is not optimal.

Teaching material is one of the important components needed in the learning process. Teaching materials are the tools that created by teachers efficiently to help learners in mastering the aim of learning process [4]. Teaching material is basically a material specifically designed for learning purposes. Teaching material is also a package of well-organized material so as to make a condition that allows students to learn well and comfort. The ability of teachers to design or compile material or teaching materials is one of the things that is very instrumental in determining the success of learning and learning processes [1]. Therefore, the teacher as the presenter of the material must be able to choose a method or approach that is in accordance with the conditions of students' abilities in the classroom, including suitability in developing teaching materials to support the learning activities. To address this, it is necessary to develop teaching materials so that students are able to find the concepts of the material being studied which can then convey concepts that are understood to others so that learning will become more meaningful. It suggests that good teaching materials include certain characteristics, 
they are: a) Giving interest in reading; b) Written and designed for students; c) Explain instructional objectives; d) Arranged based on flexible learning patterns; e) Structure based on student needs and the final competition to be achieved; f) Providing opportunities for students to practice; g) Accommodating student difficulties; h) Give a summary; i) Communicative and semi-formal writing style; j) Density based on student's needs; k) Packed for instructional processes; 1) Has a mechanism for collecting feedback from students; m) Explain how to study teaching materials [10]. Thus it can be concluded that the existence of appropriate teaching materials is expected to help smooth learning activities and the importance of teaching materials in the learning process is no doubt.

Good teaching materials will be used optimally if supported by learning models that can enable students to use these teaching materials. One of the learning methods that is expected to improve thinking and analysis skills of students on grammar material is by using cooperative learning methods. Cooperative learning is a learning model that emphasizes group learning activities. It defines cooperative learning model as a learning strategy that involves students in group activities to complete certain tasks with the hope that every students have contribution in learning process and results obtained [7]. It concludes that group learning/ collaboration is believed to be the most effective way in teaching learning process because students are actively involved in sharing ideas and work to complete academic assignments [8]. The purpose of choosing this teaching model is to make the teaching and learning process more effective in order to increase students' absorption of the subject matter, because from the facts that are found in field, what is achieved is far from what is expected. Jigsaw is one of teaching methods that can be used in learning cooperative. This method can be used for students in several level especially for students who already understand about reading and know about skills in group [6].

Students' knowledge of grammar can be improved by practicing analytical skills. Jigsaw learning model can make it easier for students to carry out analytical activities and can improve student understanding of material for better. This jigsaw cooperative learning model is a learning process which students learning in several small groups consisting of four to six heterogeneous students and working together to solve the questions given by teacher [5]. Jigsaw type cooperative learning models have differences with other learning models. The strength of Jigsaw is more effective and more efficient to apply in learning process. This is because in addition to better academic achievement of students, other things such as cooperation, intimacy, communication between students and teachers will be better along with the increase in student confidence. [3] In addition, it also stated that the Jigsaw type of cooperative learning model has advantages including: 1) Improving students' responsibility to their own learning and also to others. 2) Increasing students' knowledge 3) Students are taught how to work together in groups. 4) Apply the guidance of fellow friends. 5) A deeper understanding of the material [9].

In facilitating teachers to apply Jigsaw model based learning, teachers can arrange teaching materials such as modules. The modules compiled contain materials, learning steps according to the Jigsaw model and learning outcomes assessment instruments summarized in some practice questions at the end of each discussion chapter. Modules are a form of printed teaching material that is presented systematically, so users can learn with or without the teacher [11]. Learning by using modules aims to: (1) students are able to learn independently or with the help of the teacher to a minimum, (2) the role of the teacher does not dominate and is not authoritarian in learning, (3) trains student honesty, (4) accommodates various levels and speeds student learning, and (5) students can measure their own mastery of the material being studied [2]. Based on the explanations above it can be concluded that the module is one of alternative teaching materials that can be developed in supporting the learning process of students in achieving learning objectives.

\section{METHOD}

This type of research is a quasi-experiment involving 15 students of PKBM Bina Saiyo Pariaman City who were enrolled in the 2018/2019 school year as a research sample. The sampling technique used was purposive sampling because of the limitations of the classes available in the research area. The instrument of data collection in this study is a paper and pencil test. The conclusion of the study was taken by comparing the results of data analysis using paired sample t-tests and the findings obtained during the research activities.

\section{RESULTS AND DISCUSSION}

This study aims to look at the differences in grammar abilities of students studying in the B B PKBM Bina Saiyo Pariaman Package before and after the use of a Jigsaw model based English module. Learning is carried out in three stages, namely introduction to the material, elaboration of the material and practice questions. Overall learning activities have been well illustrated in the English module based on Jigsaw learning models. To assess the module's effectiveness statistically, an analysis is carried out in the form of data normality testing activities, data homogeneity and the effect of product use in learning activities.

Before analyzing the data to determine whether there are significant differences between before and after the use of the module on students' grammar understanding, the data group is first subjected to a prerequisite test, one of which is the normality test. To conduct a normality test analysis, the SPSS application is used using the Kolmogorov-Smirnov test type. The results of the normality test analysis for the data groups before and after treatment are presented in Table 1. 
Table 1. Result of Analysis One-Sample KolmogorovSmirnov Test Before Treatment

\begin{tabular}{|l|l|r|}
\hline \multicolumn{2}{|l|}{ Variables } & Values \\
\hline $\mathrm{N}$ & Mean & 15 \\
\cline { 2 - 3 } & $\begin{array}{l}\text { Std. } \\
\text { Normal Parameters }\end{array}$ & 5.1333 \\
\hline \multirow{2}{*}{ Most Extreme Differences } & Absolute & 1.35576 \\
\cline { 2 - 3 } & Positive & 0.205 \\
\cline { 2 - 3 } & Negative & 0.132 \\
\hline Kolmogorov-Smirnov Z & -0.205 \\
\hline Asymp. Sig. (2-tailed) & 0.795 \\
\hline
\end{tabular}

Based on Table 1, the conclusions regarding the results of the normality test analysis can be done by comparing the sig 2 tailed values obtained with the alpha value $(\alpha=0.05)$. Data is in the normal category if the value of sig. 2 tailed $>$ from 0.05 . Referring to the results in table 1 , it appears that the value of sig. 2 tailed $=0.552>$ from 0.05 . This indicates that the data group was given normal distribution before treatment. Furthermore, to complete the prerequisite test, a normality test for the data group after treatment is given. The results of the normality test data analysis after being given treatment are presented in Table 2.

Table 2. Result of Analysis One-Sample KolmogorovSmirnov Test After Treatment

\begin{tabular}{|l|l|r|}
\hline \multicolumn{2}{|l|}{ Variables } & \multicolumn{1}{|c|}{ Values } \\
\hline $\mathrm{N}$ & Mean & 15 \\
\hline \multirow{2}{*}{ Normal Parameters $^{\mathrm{a}}$} & Std. Deviation & 7.30931 \\
\cline { 2 - 3 } & Absolute & 0.167 \\
\cline { 2 - 3 } $\begin{array}{l}\text { Most Extreme } \\
\text { Differences }\end{array}$ & Positive & 0.167 \\
\cline { 2 - 3 } & Negative & -0.167 \\
\hline Kolmogorov-Smirnov Z & & 0.645 \\
\hline Asymp. Sig. (2-tailed) & & 0.799 \\
\hline
\end{tabular}

Table 2 shows the results that the value of sig. 2 tailed groups of data after treatment were given greater than the value of 0.05 . The conclusion that can be drawn is the group of data after being given normal distributed treatment. The first requirement for carrying out the effectiveness test has been fulfilled, namely the two groups of data have been normally distributed. The next prerequisite test conducted was homogeneity. Homogeneity test is a test regarding whether or not the variances of two or more distributions are equal. Homogeneity test is performed to find out whether the data in the variables are homogeneous or not. Homogeneity test results can be seen in Table 3 .
Table 3. Result of Homogeneity Test Before and After Treatment

\begin{tabular}{|l|r|}
\hline \multicolumn{1}{|c|}{ Variables } & \multicolumn{1}{c|}{ Values } \\
\hline Levene Statistic & 0.220 \\
\hline df1 & 1 \\
\hline df2 & 28 \\
\hline Sig. 2 Tailed & 0.643 \\
\hline
\end{tabular}

Homogeneity test results show that the group of students' test results before and after the treatment is homogeneous. This result is strengthened by statistical analysis using SPSS which shows that sig 2 value of tailed data> alpha value. The conclusion that can be drawn is the data group before and after treatment shows that the nature of the data is homogeneous. Furthermore, a paired sample t-test will be conducted to see how the influence of the use of English language modules based on the Jigsaw model on students' understanding of package B in PKBM Bina Saiyo. The results of data analysis using paired sample ttest are shown in table 4.

Table 4. Result of Paired Sample t-test Before and After Treatment

\begin{tabular}{|l|r|}
\hline \multicolumn{1}{|c|}{ Variables } & \multicolumn{1}{c|}{ Values } \\
\hline Mean & 4.567 \\
\hline Std. Deviation & 1.382 \\
\hline Std. Error Mean & .252 \\
\hline T & 18.102 \\
\hline Df & 29 \\
\hline Sig. (2-tailed) & 0.000 \\
\hline
\end{tabular}

Paired sample t-test will later confirm the conclusion that there are significant differences in results between before and after treatment is given in learning activities. Conclusions can be drawn by comparing the sig 2 tailed value and the alpha value that has been set. The conclusion found based on the results of the analysis; there are significant differences of students' grammar knowledge before using an English module which created based on Jigsaw learning models and after using it. The results of a significant increase in average can also be seen from the values before and after treatment.

The application of Jigsaw learning model is one of the efforts that teachers can do to reduce student boredom which is the main problem in learning activities. The teacher's tendency to use the lecture method will have an impact on the understanding and mastery of student material [12]. The application of the lecture method has been considered the most practical in terms of preparation and implementation but has not been very effective in increasing students' independence in learning.

Increasing students' grammar understanding using English modules based on Jigsaw learning models can be observed during research activities. The concept of systematic and structured learning makes the learning process more directed. Grammar understanding is strongly supported by the availability of preliminary information provided by the teacher systematically and the existence of training activities to train students' grammar 
understanding. The use of English modules based on the Jigsaw model is proven to be significantly and strengthened by statistical analysis can improve students' grammar understanding.

The main activities of students during the learning process using the Jigsaw model are listening to the teacher or other students' explanations, taking notes as needed, studying student worksheets/ teaching materials, discussing with other students. The teacher acts as a monitor, guide, and motivator $[13,14]$. Student activities in the form of discussions in the original group and expert groups give students chance to express their opinions, so as to stimulate them more creative in learning activities [15]. The jigsaw learning model is also able to handle the problems of students who lack good cooperative attitude with their friends when in groups. In this model, students will collaborate with their friends because in the application of this jigsaw learning model, students are faced with two different groups namely the original group and the expert group [17].

The application of an English module based on the Jigsaw model can increase students' interest in doing the exercises because in their learning students are divided into groups and each member has a different role. The strength of the developed English language module lies in the integration of the Jigsaw model in learning activities. Jigsaw models in theory and practically can make it easier for students to do the exercises and can make time efficient.

The modules developed are designed to be as attractive as possible with key words making it easier for students to remember the material. The exercises contained in the module are also designed so that students do not get bored reading modules that are implemented in learning activities. Workmanship activities supported by ease in the distribution of tasks, students are divided into two groups, namely the expert group and the home group. Increased understanding of grammar will be greatly supported by this jigsaw activity, because each student has a contribution and responsibility so that other students in the group origin understand the material they have discussed in the expert group.

The use of Jigsaw learning models can not only improve students 'grammar abilities, but can also trigger other impacts such as training students' writing skills. Writing skills are particularly very important for students in their schooling days. They are very often need to write reports and some other types of writing, so that writing activities cannot be avoided. Within the university environments, the students have to deal with various types of written discourse including narration, description, exposition, and argumentation [17].

The role and responsibility of students in outlining the training material to friends becomes one of the points that will have an impact on increasing students' grammar understanding both for themselves and other students. Basically, students' understanding will be better if the student is able to repeat and explain the material he has understood to other friends. Understanding grammar material can also be built not only through interactions between teachers and students, but also students and students. This is supported by social constructive theory which states that the concept of learning is not only the result of one's own understanding but is the result of interaction between students and their social environment, both knowledge that is built based on understanding with students/ other friends, teachers, community environment and others

The development of an English module based on the Jigsaw model is still limited in terms of material. The limitation of researchers who have only designed modules developed in package $\mathrm{B}$, makes the context and impact of the modules developed not yet felt at other levels of education. In the future it is hoped that other researchers can develop English language modules based on the Jigsaw model in other educational materials or levels. In learning English, a support system such as media is also needed so that it can help the implementation of the Jigsaw model in its entirety [18]. Learning styles can also be one of the considerations in designing and designing these support systems [19].

\section{CONCLUSIONS}

The application of English modules based on Jigsaw models is theoretically proven and can improve students' understanding of grammar package B. The application of English modules based on Jigsaw models must be supported by careful planning by the teacher. Things that need to be considered during the learning activities using an English language module based on the Jigsaw model include: the availability of reference material as initial information for students in starting learning activities, facilities and infrastructure as well as the composition and mapping of student learning time.

\section{REFERENCES}

[1] Yuliana Gazali, Rahmita. (2016). Pengembangan Bahan Ajar Matematika untuk Siswa SMP Berdasarkan Teori Belajar Ausabel. PYTAGORAS: Jurnal Pendididkan Matematika. Vol.II No.2 (182.192). Doi:http ://journal.uny.ac.id/index.php/pythagoras

[2] Novita Tjiphanty, Endang, dkk, (2016). Pengembangan Modul Pembelajaran Matematika dengan Pendekatan Inkuiri untuk Membantu Siswa SMA Kelas X dalam Memahami Materi Peluang. Jurnal Pendidikan : Teori, Penelitian, dan Pengembangan. Vol. 1 No. 10 (Hal. 1938-1942)

[3] Putri Hijrihani, Curie. (2015). Keefektifan Cooperative Learning Tipe Jigsaw \& STAD Ditinjau dari Prestasi Belajar \& Kepercayaan Diri Siswa. PYTHAGORAS: Jurnal Pendidikan Matematika. Vol. 10. No 1 (Hal. 1 - 14).

[4] Ardiansyah, Reza dkk. (2017). Pengembangan Bahan Ajar Mutasi Genetik pada Mata Kuliah Genetika. Jurnal Pendidikan: Teori Pendidikan, dan Pengembangan Vol. 2. No.7 (Hal. 927-933). Doi : http://journal.um.ac.id/index.php/jptpp/ 
[5] Ali Imron, Yasri, et al. (2017). Penerapan Model Pembelajaran Kooperatif Tipe Jigsaw untuk Meningkatkan Prestasi Belajar Siswa pada Mata Pelajaran Alat dan Mesin Pertanian (PTK Pada Siswa Kelas XI Penyuluh Pertanian SMK Negeri 2 Walerang). Jurnal Pendidikan Teknologi Pertanian. Vol. 4. No.3

[6] Basuki, Nur. (2015). Peninkatan Aktivitas \& Hasil Belajar Siswa Menggunakan Model Pembelajaran Kooperatif Tipe Jigsaw Pada Mata Pelajaran Matematika Siswa Kelas VII SMPN 2 Bumiratu Nuban Tahun Pelajaran 2014/2015. AKSIOMA: Jurnal Program Studi Pendidikan Matematika Vol. 4. No.1. Doi :http//dx.doi.org/10.24127/ajpm.v4i1.96

[7] Suherman, Asep. (2016). Pengaruh Penerapab Model Kooperatif Tipe Jigsaw dan TGT (Teams Game Tournament) Terhadapa Keterampilan Sosial dan Keterampilan Bermain Bola Voli. Jurnal Pendidikan Jasmani \&Olahraga. Vol. 1. No. 2

[8] Rosyidah, Ummu. (2016). Pengaruh Model Pembelajaran Kooperatif Tipe Jigsaw Terhadap Hasil Belajar Matematika Siswa Kelas VII SMP Negeri 6 Metro. Jurnal SAP Vol. 1. No. 2

[9] Aprilya, Riesky dkk. (2015). Penerapan Model Pembelajaran Kooperafif Tipe Jigsaw Sebagai Upaya Meningkatkan Prestasi Belajar Pada Mata Pelajaran Rencana Anggaran Biaya Kelas X Program Studi Teknik Sipil SMK Negeri t Surakarta. Jurnal Pendidikan Teknik Bangunan www.jurnal.fkip.uns.ac.id/index.php/ptb/article/vi ew/5222

[10] Yuntanti \& Lalu Abdul Aziz. (2018). Pengembangan Modul Kalkulus II Menggunakan Model Kooperatif Model Jigsaw Berbasis Inquiry. Jurnal Ilmiah IKIP Mataram Vol. 4. No. 1

[11] Sumiati, Eli et al. (2018). Pengembangan Modul Fisika Berbasis Scientific Approach Untuk Meningkatkan Keterampilan Proses Sains Siswa. Jurnal Pendidikan Fisika \& Keilmuan (JPFK). Vol. 4. No. 2 (Hal. 75-88)

[12] Zakirman, Z., Lufri, L., \& Khairani, K. (2019, January). Factors Influencing the Use of Lecture Methods in Learning Activities: Teacher Perspective. In International Conference on Islamic Education (ICoIE 2018). Atlantis Press.

[13] Haryanto, Toni. (2017). Upaya Tutor Kesetaraan Paket B Dalam Meningkatkan Proses Belajar Peserta Didik Di Pkbm Geger Sunten. Jurnal Pendidikan Luar Sekolah, 1(1), 37-51.

[14] Pujianasari, R., Sutji Wardhayani \& Jaino. (2016). Keefektifan Model Jigsaw Terhadap Hasil Belajar IPA Siswa Kelas IV. Jurnal Kreatif September, 92-101.

[15] Saiful Alfazr, A., Diah Gusrayani \& Dede Tatang Sunarya. (2016). Penerapan Model Pembelajaran
Jigsaw Untuk Meningkatkan Hasil Belajar Siswa Dalam Menemukan Kalimat Utama Pada Tiap Paragraf. Jurnal Pena Ilmiah, 1(1), 111-120.

[16] Puspa Adhi, A.A., Istri Ngurah Marhaeni \& N Bawa Atmadja. (2013). Pengaruh Pendekatan Kooperatif Tipe Jigsaw Dalam Pembelajaran Bahasa Inggris Terhadap Prestasi Belajar Menulis Ditinjau Dari Bakat Verbal Siswa Smp Negeri 2 Amlapura. e-Journal Program Pascasarjana Universitas Pendidikan Ganesha, 4, 1-11.

[17] Gusta, W. (2017). An Analysis Of English Students'paragraphs Development Of Argumentative Essay: A Study At English Department Of Iain Imam Bonjol Padang. journal of residu, 1(1), 85-92.

[18] Zakirman, Z., \& Hidayati, H. (2017). Praktikalitas Media Video dan Animasi dalam Pembelajaran Fisika di SMP. Jurnal Ilmiah Pendidikan Fisika Al-Biruni, 6(1), 85-93.

[19] Zakirman, Z. Z. (2017). Pengelompokkan Gaya Belajar Mahasiswa Menurut Teori Honey Mumford Berdasarkan Intensitas Kunjungan Pustaka. RISTEKDIK: Jurnal Bimbingan dan Konseling, 2(2). 